\title{
Sosyal İzolasyonun Örgütsel Sinizm Üzerindeki Etkisi
}

\author{
Ali ERBAŞI* $\quad$ Orhan ZAGANJORI ${ }^{* *}$
}

\begin{abstract}
$\ddot{O} Z$
Bu çalışmanın amacl, sosyal izolasyonun örgütsel sinizm üzerindeki etkisini incelemektir. Bu amaçla Konya ilinde bulunan 5 tarım makineleri üretim işletmesinin 162 çalışanına uygulanan anketlerden elde edilen veriler değerlendirilmiştir. Değerlendirmelerde merkezi eğilim ölçüleri ve tanımlayıcı istatistikler kullanılmış, korelasyon ve regresyon analizleri ve manova testi uygulanmıştır. Araştırmanın bulgularına göre, sosyal izolasyonun örgütsel sinizm üzerinde istatistiksel açıdan anlamlı etkisinin olduğu tespit edilmiştir. Ayrıca sosyal izolasyonun örgütsel sinizm boyutlarl üzerindeki etkisi incelenmiş, buna göre sosyal izolasyonun üç örgütsel sinizm boyutunu da (duyuşsal, bilişsel ve davranışsal) istatistiksel açıdan anlamlı şekilde etkilediği görülmüsşür. Çalışanların sosyal izolasyon düzeylerinin en çok duyuşsal sinizmi etkilediği bulgulanmıştır. Ayrıca sosyal izolasyon düzeyinin bilişsel sinizmi yüksek düzeyde, davranışsal sinizmi ise düşük düzeyde etkilediği sonucuna ulaşılmıştır.
\end{abstract}

davranıssal sinizm.

Anahtar Kelimeler: Sosyal izolasyon, örgütsel sinizm, duyuşsal sinizm, bilişsel sinizm,

JEL Sinıflandirması: D23, M19.

\section{The Effect of Social Isolation on Organizational Cynicism}

\begin{abstract}
The aim of this study is to investigate the effect of social isolation on organizational cynicism. For this purpose, data obtained from questionnaires implemented to 162 employees works in 5 agricultural machinery production private company located in Konya were evaluated. In the evaluation, measures of central tendency and descriptive statistics were used, correlation and regression analysis and manova analysis were performed. The results showed that social isolation has statistically a significant effect on organizational cynicism. Also, the effect of social isolation on organizational cynicism dimensions were investigated. According to the findings, social isolation has statistically significant effect on three dimensions of organizational cynicism (affective, cognitive and behavioral). It has been found to social isolation has most effect on affective cynicism. Also, it has reached the conclusion that social isolation affect cognitive cynicism high level and behavioral cynicism low level.
\end{abstract}

Key Words: Social isolation, organizational cynicism, affective cynicism, cognitive cynicism, behavioral cynicism.

JEL Classification: D23, M19.

\section{GİRIŞ}

Sosyal izolasyon kavramı, daha çok sağlık bilimleri ve eğitim bilimleri alanlarının ilgi alanı olagelmiştir. Kavramın sosyal bilimler alanında kullanımı ise oldukça sınırlıdır. Kavram, işletme alanyazını özelinde incelendiğinde bu sınırlılık kendisini daha da hissettirmektedir. $\mathrm{Bu}$ sınırlılıklar eşliğinde, çalışmamızda sosyal izolasyon, işletmelerdeki çalışanlar açısından ele alınmıştır.

\footnotetext{
* Doç. Dr. Selçuk Üniversitesi İktisadi ve İdari Bilimler Fakültesi, İşletme Bölümü. aerbasi @ selcuk.edu.tr **zaganjori.orhan@gmail.com
} 
İşe yabancılaşma ve örgütsel sinizm ilişkisi (Kökalan ve Anaş, 2016; Yıldız vd., 2013; Akman, 2013: 43) ele alındığında, sinik tutuma sahip çalışanların işlerine yabancılaştıkları görülmektedir. $\mathrm{Bu}$ yabancılaşmanın beraberinde, çalışanın kendisini sosyal açıdan izole etmesini getirebileceğini söyleyebiliriz. Ayrıca mobbinge uğrayan çalışanların genel olarak çalışma arkadaşlarından izole olmaları gibi durumlar, çalsşanların sinik tutumlar sergilemesine neden olabilecektir (Gün, 2016: 217). Bu bağlamda sosyal açıdan izole olmuş çalışanların hayata olumsuz bakış açılarının olacağını söyleyebiliriz. Sosyal açidan izole olmuş çalışanların işletmeye karşı olumsuz tutum içerisinde olabilecekleri varsayımıyla araştırmanın modeli kurulmuştur. $\mathrm{Bu}$ doğrultuda sosyal izolasyonun örgütsel sinizm üzerindeki etkisi, Konya ili tarım makineleri endüstrisindeki çalışanlar evreninde incelenmiştir. Bu amaçla öncelikle örgütsel sinizm ve sosyal izolasyon kavramlarıyla ilgili kavramsal çerçeve oluşturulmuş, bu süreçte amaca yönelik çeşitli hipotezler geliştirilmiştir. Sonrasında araştırmanın metodolojisine ilişkin bilgiler verilmiş ve uygulama süreci aktarılarak sonuçlar tartışılmışıır.

\section{KAVRAMSAL ÇERÇEVE}

\section{A. Örgütsel Sinizm}

Sinizm bir davranışı o davranışın arka planında yatan detaylarla pozitif görünümlerin maskesinden arındırarak açıklamaya çalışan ve altta yatan daha temel motivasyonlarla hırs, açgözlülük, güç, arzu, düşkünlük ve bencillik açılarından inceleyen bir kavramdır (Keyes, 2006: 11). Bu bağlamda sinik davranışlar, her ne kadar olumsuz bir durumu ifade etse de, kavramın altında samimi düşüncelerin yattı̆̆ını söyleyebiliriz (van Erp and Verstricht, 2008: 7). Politika ile ilgilenen bilim insanları ise, sinizmi başarısız olmuş sözlerin, politikaların ve performansların ürünü olarak görmektedir (Cappella ve Jamieson, 1997: 28).

Oxford Sözlügüne (2010: 434) göre sinizm, insanların çıkarcı hareketlerine olan inancın eğilimi olarak tanımlanır. Sinik kişi ise, onurlu ve çıkarcı olmayan hareketlerdense, çıkarını düşünen hareketleri tercih eden kişi olarak tanımlanmaktadır. Vice'a (2011) göre sinizm uyuşmazlık, güvensizlik ve şüpheciliğin kombinasyonudur. Yazara göre sinizm, insan davranışlarının şahsi çıkarlar üzerine kurulu olduğunu ifade eden bir kavramdır.

Sinizm, bugünün toplumları için genel bir ruh hali durumuna gelmiştir (Krings-Ernst, 2011: 2). Aynı zamanda sinizm bir tavır haline gelmiş sosyal bir atmosfer durumundadır (Mozella, 2007: 182). Sinizm, genellikle olgunlaşmamış tavırları içinde barındırır (Schreier, 2009: 8). Sinizm, güvene karşı tepki olmakla beraber örgütlere zarar verir. Çünkü sinik davranışların altında "Bunlara inanmıyorum, hiçbir zaman işe yaramayacak" düşüncesi hakimdir (Bibb ve Kourdi, 2004: 124). Sinik çalışanlar, organizasyonel eylemlerin adalet, dürüstlük ve samimiyetten yoksun olduğunu düşünürler (Graen and Graen, 2006: 193).

Sinizm ile ilgili olarak en yaygın kullanılan kavram örgütsel sinizmdir. Dean ve arkadaşları (1998: 345) örgütsel sinizmi, kişinin kuruma karşı negatif tavrı olarak tanımlamış ve üç boyuttan oluştuğunu vurgulamışlardır. Bunlardan 
ilki, örgütsel bütünlüğün olmadığına olan inançtır. İkincisi örgüte karşı negatif hareketlerde bulunmak, üçüncüsü ise küçümseme eğilimi ve bu inanç ve davranışlar ile tutarlı örgüte karşı yapılan kritik davranışlardır. Bu üç boyut üç bileşene karş1lık gelmektedir. (1) Örgütsel sinizmin duyuşsal boyutu, örgüte karş1 duygusal tepkiyi ifade eder. (2) Örgütsel sinizmin bilişsel boyutu, örgütün dürüst olmadığı yönündeki inançtır. (3) Örgütsel sinizmin davranışsal boyutu ise negatif eğilimleri ve aşağılayıcı tutumları içermektedir. Örgütün tutarlı davranışlarının olmayışına inanmaktan doğan güvensizlik, çalışanların organizasyonu çok sert bir şekilde eleştirmesi ve müşteri ve çalışanlara karşı yapılan haksızlıkların gündeme gelmesini sağlayacak sonuçlar doğurur (Clegg and Bailey, 2007: 355).

\section{B. Sosyal İzolasyon}

Sosyal izolasyon, kişinin diğer bireylerle ilişkisinin olmaması ya da çok az sayıda anlamlı bağlarının olması anlamına gelmektedir (de Jong et al., 2006: 486). Samuel ve arkadaşlarına (2014: 3) göre sosyal izolasyon, yaşayan insanın kendisini bir kuyunun dibinde yalnız oturuyor gibi hissetmesi ve çektiği acıdan kimsenin haberi olmadığını, kimsenin umursamadığını, seslenirse sesinin duyulmayacağını ve dünyada görünmez olduklarını düşünmesiyle açıklanabilir.

Biordi ve Nicholson (2013) sosyal izolasyonun güçsüzlük, yabancılaşma, anlamsızlık ve kendinden soğuma gibi duyguları içerdiğini ve yalnızlıkla bağlantılı olduğunu ifade etmektedir (Brown et. al., 2015: 72). Bu akademik tanımların ötesinde sosyal izolasyonu tamamen insani ve kişisel tecrübelerin sonucu olarak gören bir bakış açısı mevcuttur (Samuel, 2015: 1).

Kişiler, az sayıda anlamlı sosyal ilişkileri olduğunda, yalnız kalmayı tercih ederler ve böylece sosyal izolasyonun şartları oluşur. Sürekli yalnızlık, genel olarak depresyon ve düşük öz sayg1 gibi ciddi problemlerle sonuçlanır (Hortulanus et. al., 2006: 37). Bazı çalışmalarda sosyal izolasyon ve yalnızlık, patolojik bir olgu olarak tanımlanmakta ve gelecekteki hayatın pozitif yönlerini anlamaktaki eksikliğe bağlanmaktadır (Victor et. al., 2008: 31).

Sosyal izolasyon, sosyal politikanın üç hedefi ile ilişkilidir: Üstesinden gelebilme, sosyal katılım ve sosyal bağlılık (Hortulanus et. al., 2006: xxv). Bu açıdan bakıldığında sosyal izolasyon, sosyal bağlılıklarının az olmasından dolayı çalışanların diğerlerine karşı yaşadığı iletişimsizliği de içerir. Örnek olarak Rokach ve Wright (2013: 49) organizasyonların başındaki yöneticilerin iş arkadaşlarıyla arasındaki zorunlu hiyerarşiden dolayı sosyal izolasyon yaşadıklarını vurgulamaktadırlar.

Sosyal izolasyon kavramı, literatürde daha çok sağlık bilimleri ve eğitim bilimleri alanlarında kullanılagelmiştir. Kavramın sosyal bilimler alanındaki kullanımı ise oldukça sınırlıdır. Bu çalışmalara örnek olarak; Rovai (2014) sosyal destek, güçsüzlük ve normsuzluk arasındaki karmaşık yapıyı açıklamaya çalışmıştır. Reeder ve Reeder (1969) sosyal izolasyon ve yasadışı davranışları; Laursen ve arkadaşları (2007) sosyal izolasyon ve genç çocuklukta yaşanan problemlerin ilişkisini incelemiştir. Siegel (1998) sosyal izolasyonun çocukluktaki ilk belirtilerini incelemiş; Bachrach (1980) yaşlılardaki çocuksuzluk 
ve sosyal izolasyon ilişkisini ele almıştır. Hawton ve arkadaşları (2011) sosyal izolasyonun sağlık üzerindeki etkilerini ve yaşlıların sağlıklı yaşamları ile iliş̧isini araştırmıştır. Cornwell ve Waite (2009) yetişkinlerdeki sosyal bağlantısızlık, algılanmış izolasyon ve sağlık arasındaki ilişkileri çözmeye çalışmıştır. Karelina ve arkadaşları (2009) sosyal izolasyon ve inme hastalığ 1 arasındaki ilişkiyi incelemişken; Cacioppo ve arkadaşları (2010) algılanan sosyal izolasyon, yalnızlık ve depresif semptonlar ilişkisini araştırmışlardır. Geschwender (1968) tutarsızlık, sosyal izolasyon ve kişisel huzursuzluğu inceleme konusu yaparken; Elliot (1999) düşük seviyede eğitime sahip çalışanlar üzerinde sosyal izolasyon, ağlar ve çevre etkisini incelemiştir. Uribe (2007) sosyal izolasyonun sosyal destek ile ilişkisini incelerken; Tigges ve arkadaşları (1998) fakirliğin, ırkın, sınıfın, çevrenin ve sosyal kaynakların sosyal izolasyonla ilişkisini irdelemişlerdir.

Sosyal izolasyon kavramının işletme alanındaki kullanımı ise oldukça sınırlıdır. Sosyal izolasyon kavramının işletme alanyazınındaki kullanımı, genellikle mobbing ile ilişkilidir. Bu çalışmalarda (örneğin Acar ve Dündar, 2008; Leymann, 1990) sosyal izolasyon, mobbingin bir sonucu veya nedeni olarak ele alınmaktadır. Alanyazın taramasında, sosyal izolasyon ile örgütsel sinizm arasındaki ilişkiyi ele alan herhangi bir araştırmaya rastlanmamıştır.

Yukarıda aktarılan kavramsal çerçeveden yola çıkarak aşağıdaki hipotezler geliştirilmiştir.

$\mathrm{H}_{1}$ : Sosyal izolasyon, duyuşsal sinizmi etkiler.

$\mathrm{H}_{2}$ : Sosyal izolasyon, bilişsel sinizmi etkiler.

$\mathrm{H}_{3}$ : Sosyal izolasyon, davranışsal sinizmi etkiler.

Geliştirilen hipotezler doğrultusunda kurulan araştırma modeli Şekil 1'de gösterilmiştir.

Şekil 1. Önerilen Araştırma Modeli

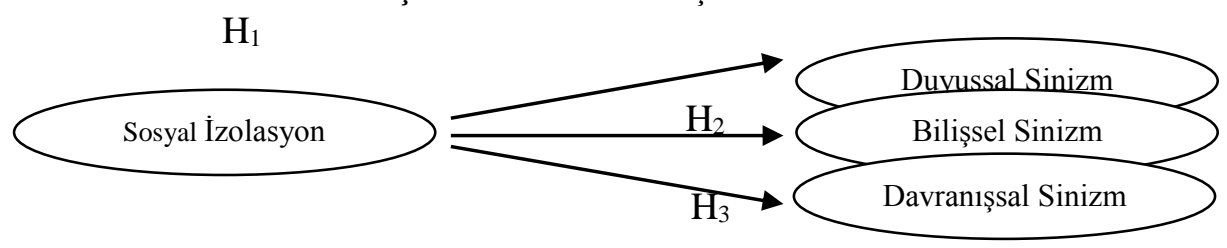

\section{METODOLOJİ}

\section{A. Araştırmanın Deseni ve Yöntemi}

$\mathrm{Bu}$ araştırma, nicel araştırma yaklaşımı türünde desenlenmiş olup, araştırmada deneysel olmayan yöntemlerden ilişkisel araştırma yöntemi kullanılmıştır.

\section{B. Araştırmanın Sorusu ve Amacı}

$\mathrm{Bu}$ araştırmada "Çalışanların sosyal izolasyon düzeyi ile örgütsel sinizm ilişkisi nedir?" temel sorusuna cevap aranmaktadır. Bu problematiğe dayalı olarak bu çalışmanın temel amacı; çalışanların sosyal izolasyon düzeyinin örgütsel sinizm üzerindeki etkisini incelemektir. 


\section{Evren ve Örneklem}

Araştırmanın evrenini, Konya ilinde tarım makineleri endüstrisinde faaliyet gösteren 5 imalat işletmesinin çalışanları oluşturmaktadır. Bu doğrultuda 5 tarım makineleri imalatçısı işletmenin 245 çalışanının tümüne anketler dağıtılmıştır. Böylece araştırmada evren ve örneklem ayrımı yapılmamaya çalışılmıştır. Ancak bazı çalışanlar anket doldurmaya istekli olmadığından ve anketin yapıldığı günlerde çeşitli nedenlerle işletmede olmayan veya ulaşılamayan çalışanlara anket uygulanamamış, toplam 173 çalışana anket uygulanmıştır. Dolayısıyla anketlerin geri dönüm oranı \%70,6'dır. Verilerin toplanmasında yaklaşık 7-8 dakika süren (kağıda basılı) anket yöntemi kullanılmıştır. Analizler öncesi kayıp veri ve temel değişkenler üzerinden yapılan incelemeler sonucunda, 11 anket analizden çıkarılmış, analizler 162 kişilik bir örneklemden elde edilen verilerle yapılmıştır.

Araştırmaya katılan örneklemin demografik özelliklerine bakıldığında (Tablo 1), katılımcıların büyük çoğunluğunun erkek, evli, 18-49 yaş aralığında, yüksek eğitimli, açlık ve yoksulluk sınırının altında gelire ve 1-7 yıl arasında sektör deneyimine sahip olduğu görülmektedir.

Tablo 1. Demografik Değişkenlere Göre Frekans Dağılımları $(\mathrm{n}=162)$

\begin{tabular}{|c|c|c|c|}
\hline \multicolumn{2}{|c|}{ Demografik Değişken } & \multirow{2}{*}{$\begin{array}{c}\text { Frekans } \\
148\end{array}$} & \multirow{2}{*}{$\frac{\text { Oran }(\%)}{91,4}$} \\
\hline Cincivet & Erkek & & \\
\hline Cinsıyet & Kadın & 14 & 8,6 \\
\hline \multirow{2}{*}{ Medeni Durum } & Evli & 106 & 65,4 \\
\hline & Bekar & 36 & 34,6 \\
\hline \multirow{4}{*}{ Yaş } & $18-29$ aras1 & 52 & 33,3 \\
\hline & $30-49$ aras1 & 70 & 43,2 \\
\hline & $50-65$ aras 1 & 32 & 19,8 \\
\hline & 66 ve üstü & 6 & 3,7 \\
\hline \multirow{6}{*}{ Eğitim } & İlkokul & 3 & 1,9 \\
\hline & Ortaokul & 6 & 3,7 \\
\hline & Lise & 62 & 38,3 \\
\hline & Önlisans & 24 & 14,8 \\
\hline & Lisans & 62 & 38,3 \\
\hline & Yüksek lisans & 5 & 3,0 \\
\hline \multirow{3}{*}{ Aylık Gelir } & 1225 TL ve altı & 44 & 27,2 \\
\hline & $1226-3990$ TL aras1 & 110 & 67,9 \\
\hline & 3991 TL ve üstü & 8 & 4,9 \\
\hline \multirow{5}{*}{ Sektördeki İş Deneyimi } & 1 y1ldan az & 10 & 6,2 \\
\hline & 1-3 y1l arası & 48 & 29,6 \\
\hline & 4-7 y1l aras1 & 56 & 34,6 \\
\hline & 8-11 y1l arası & 28 & 17,3 \\
\hline & 12 yildan fazla & 20 & 12,3 \\
\hline
\end{tabular}




\section{Veri Analizi}

Araştırmada elde edilen veriler, SPSS 21.0 programı aracılı̆̆ıyla çözümlenmiş̧ir. Verilerin analizinde tanımlayıcı istatistikler, geçerlilik ve güvenilirlik testleri, korelasyon ve regresyon analizi ve tek yönlü manova analizi kullanılmıştır.

\section{E. Araştırmada Kullanılan Ölçüm Araçları}

Araştırmada ölçüm aracı olarak, 3 bölümden oluşan bir anket formu kullanılmıştır. Anketin ilk bölümünde Tablo 1'de gösterilen katılımcılara ait demografik değişkenler sorgulanmıştır. Araştırmanın ikinci bölümünde sosyal izolasyonu ölçmeye yönelik olarak, Nottingham Health Profile (NHP)'nin olguların yaşam kalitesini değerlendirmek amacıyla geliştirdiği anketin 6 alt bölümden birisi olan sosyal izolasyon ölçeği kullanılmıştır. Ölçeğe ait ifadeler Küçükdeveci vd. (2000) tarafindan Türkçe'ye uyarlanan ve Kılıç (2009)'ın uzmanlık tezinde kullandığı Türkçe tercümeden alınmıştır. Bu ölçekte 5 soru bulunmaktadır. Anketin üçüncü ve son bölümünde ise Brandes vd. (1999) tarafından geliştirilen örgütsel sinizm ölçeği kullanılmıştır. Ölçeğe ait ifadeler, Karacaoğlu ve İnce (2012) tarafından Türkçe'ye yapılan uyarlamadan alınmıştır. Bu ölçekte 13 soru bulunmaktadır. Anketin ikinci ve üçüncü bölümünde yer alan her iki ölçekte de; "1. Kesinlikle katılmıyorum" ... "5. Kesinlikle katılıyorum" aralığında değişen 5'li Likert ölçeği kullanılmıştır. (1) düşük sosyal izolasyon ve düşük sinizm düzeyini, ......., (5) yüksek sosyal izolasyon ve yüksek sinizm düzeyini temsil etmektedir. Dolayısıyla değerlendirmeler yapılırken 5'e doğru yaklaştıkça sosyal izolasyon ve sinizm düzeyinin arttığı, 1'e doğru yaklaştıkça sosyal izolasyon ve sinizm düzeyinin azaldığı yorumu yapılmıştır.

Araştırmada kullanılan ölçeklerin boyutlarını kontrol etmek ve değişkenler arası ilişkide tek boyutluluğu sağlamak amacıyla açıklayıcı faktör analizi yapılmıştır (Tablo 2). Açıklayıcı faktör analizinde örneklem sayısının yeterliliğini gösteren Kaiser Meyer Olkin (KMO) testinin yanı sıra, "korelasyon matrisi birim matrise eşittir" şeklinde ifade edilen sıfır (yokluk) hipotezinin "korelasyon matrisi birim matrise eşit değildir" alternatif hipotezine karşı sınanması ve sıfır hipotezinin reddedilmesi gerekmektedir. Bu ise küresellik adı verilen Barlett testi ile kontrol edilir. Bartlett (1950) tarafindan verilerin küreselliğini açıklamak için kullanılan bu test, sonraki bazı çalışmalarda değişkenlerin tutarlılı̆̆ını açıklamak için kullanılmıştır.

$\mathrm{H}_{0}$ : $\mathrm{R}=\mathrm{I}$ (Korelasyon matrisi ile birim matris arasında fark yoktur. Değişkenler arasındaki ilişkiler önemsizdir.)

$\mathrm{H}_{1}$ : $\mathrm{R} \neq \mathrm{I}$ (Korelasyon matrisi ile birim matris arasında fark vardır. Değişkenler arasındaki ilişkiler önemlidir.) 
Tablo 2. Açıklayıcı Faktör Analizi

\begin{tabular}{c|l|r|r}
\hline \multicolumn{2}{l|}{} & $\begin{array}{c}\text { Sosyal İzolasyon } \\
\text { Ölçeği }\end{array}$ & $\begin{array}{r}\text { Örgütsel Sinizm } \\
\text { Ölçeği }\end{array}$ \\
\hline \multicolumn{2}{l|}{ Kaiser Meyer Olkin Örneklem Yeterliliği Testi } &, 804 &, 819 \\
\hline \multirow{2}{*}{$\begin{array}{c}\text { Bartlett Küresellik } \\
\text { Testi }\end{array}$} & Yaklaşık Ki-kare $\left(x^{2}\right)$ & 529,005 & 1215,633 \\
& Serbestlik Derecesi (df) & 10 & 78 \\
& p &, 000 &, 000 \\
\hline
\end{tabular}

Veri setinin uygunluğuna ilişkin yapılan KMO testi sonucu sosyal izolasyon ölçeği için 0,804 ve örgütsel sinizm ölçeği için 0,819 olarak belirlenmiştir. $\mathrm{Bu}$ sonuçlar, kabul edilebilir oran olan 0,60 (kimi kaynaklarda sosyal bilimlerdeki uygulamalar için 0,50) değerinden oldukça yüksektir. Böylece eşleştirilen değişkenlerin korelasyonlarının diğer değişkenler tarafından yüksek düzeyde açıklandığı, örneklem büyüklüğünün yeterli olduğu ve veri setinin temel bileşenler analizine uygun olduğu sonucuna ulaşılmıştır. Korelasyon matrisinin birim matrise eşit olup olmadığı hipotezini test eden Bartlett testi sonucu ise, her iki ölçek için de istatistiksel açıdan anlamlı $\times 2$ sonucu ortaya koymuş (sosyal izolasyon ölçeği için $x 2=529,005, \mathrm{df}=10, \mathrm{p}=0,000$ ve örgütsel sinizm ölçeği için $\left.\chi_{2}=1215,633, \mathrm{df}=78, \mathrm{p}=0,000\right)$ ve sıfır hipotezi reddedilmiştir. Buna göre veriler normal dağılıma sahiptir ve değişkenler arasında ilişki vardır (değişkenler uygundur).

Araştırmada kullanılan ölçeklerin ve dolayısıyla faktör yapılarının geçerlilik testleri için açıklayıcı faktör analizine başvurulmuş ve bulguları Tablo 3 'te sunulmuştur. Araştırma değişkenlerinin her biri ilgili faktörüne istatistiksel olarak anlamlı yüklenmiş olup, bu durum ölçeklerin yakınsama geçerliliğini (convergent validity) temsil etmektedir. Analiz sonucunda üç faktörlü ve 13 sorudan oluşan sinizm ölçeğine, tek faktörlü ve 5 sorudan oluşan sosyal izolasyon ölçeğine ulaşılmıştır. Sorular ve yüklendikleri boyutlar dikkate alındığında, Karacaoğlu ve İnce (2012)'nin kullandığg sinizm ölçeğine göre ve Kılıç (2009)'ın kullandığı sosyal izolasyon ölçeğine göre ankette bir değişiklik olmamıştır.

Tablo 3. Faktör Analizi Bulguları ve Cronbach Alpha Değerleri

\begin{tabular}{|l|c|}
\hline \multicolumn{1}{|c|}{ Örgütsel Sinizm Ölçeği $(\boldsymbol{\alpha}=, \mathbf{8 2 6})$} & $\begin{array}{c}\text { Standart } \\
\text { Faktör } \\
\text { Yükleri }\end{array}$ \\
\hline Duyuşsal Boyut & $\boldsymbol{\alpha}=, \mathbf{9 1 8}$ \\
\hline Çalıştığım işletmeyi düşündükçe gerilim yaşarım. &, 773 \\
\hline Çalıştığım işletmeyi düşündükçe hiddetlenirim. &, 816 \\
\hline Çalıştığım işletmeyi düşündükçe sinirlenirim. &, 872 \\
\hline Çalıştığım işletmeyi düşündükçe içimi bir endişe kaplar. &, 756 \\
\hline Bilişsel Boyut & $\boldsymbol{\alpha}=, \mathbf{8 6 3}$ \\
\hline Çalıştığım işletmenin politika, amaç ve uygulamaları arasında çok az ortak yön vardır. &, 698 \\
\hline $\begin{array}{l}\text { Çalıştığım işletmede, bir uygulamanın yapılacağı söyleniyorsa, bunun gerçekleşip } \\
\text { gerçekleşmeyeceği konusunda kuşku duyarım. }\end{array}$ &, 671 \\
\hline Çalıştığım işletmede, söylenenler ile yapılanların farklı olduğuna inanıyorum. &, 786 \\
\hline $\begin{array}{l}\text { Çalıştığım işletmede, çalışanlardan bir şey yapmaları beklenir, ancak başka bir davranış } \\
\text { ödüllendirilir. }\end{array}$ &, 857 \\
\hline $\begin{array}{l}\text { Çalıştı̆̆ım işletmede, yapıllacağı söylenen şeyler ile gerçekleşenler arasında çok az benzerlik } \\
\text { görüyorum. }\end{array}$ &, 613 \\
\hline
\end{tabular}


A. Erbaşı \& O. Zaganjori / Sosyal İzolasyonun Örgütsel Sinizm Üzerindeki Etkisi

\begin{tabular}{|l|c|}
\hline Davranışsal Boyut & $\boldsymbol{\alpha}=\mathbf{6 8 5}$ \\
\hline Başkalarıla, çalıştığım işletmedeki işlerin nasıl yürütüldüğü hakkında konuşurum. &, 834 \\
\hline Başkalarıyla, çalıştığım işletmedeki uygulamaları ve politikaları eleştiririm. &, 765 \\
\hline $\begin{array}{l}\text { Çalıştı̆̆ım işletmeden ve çalışanlarından bahsedildiğinde, birlikte çalıştığım kişilerle anlamlı } \\
\text { bir şekilde bakışırız. }\end{array}$ &, 531 \\
\hline Çalı̧şı̆̆ım işletme dışındaki arkadaşlarıma, işte olup bitenler konusunda yakınırım. &, 696 \\
\hline \multicolumn{1}{|c|}{ Sosyal İzolasyon Ölçeği } & $\boldsymbol{\alpha}=, \mathbf{8 9 4}$ \\
\hline Kendimi yalnız hissediyorum. &, 887 \\
\hline İnsanlarla ilişki kurmakta güçlük çekiyorum. &, 791 \\
\hline Kendimi hiç kimseye yakın hissetmiyorum. &, 865 \\
\hline İnsanlara ayakbağı olduğumu düşünüyorum. &, 807 \\
\hline İnsanlarla geçinemiyorum. &, 871 \\
\hline
\end{tabular}

Faktör analizi sonuçları, varyans oranları ne kadar yüksek ise ölçeğin o kadar güçlü olduğunu gösterir. Sosyal bilimlerde yapılan analizlerde \%40 ile \% 60 arasında değişen varyans oranları yeterli olarak kabul edilmektedir (Tavşancıl, 2010: 46). Araştırmanın faktör analizi bulgularına göre (Tablo 3), sinizm bileşenlerinin duyuşsal, bilişsel ve davranışsal şeklinde adlandırılarak üç boyutta incelenebileceğini ortaya koymuştur. Duyuşsal bileşen açıklanan toplam varyansın \%42,73'ünü, bilişsel bileşen \%16,17'sini ve davranışsal bileşen $\% 8,41$ 'ini temsil etmektedir. Her üç bileşen, toplam varyansın \%67,32'sini açıklamaktadır. Açıklayıcı faktör analizi bulgularından sosyal izolasyon ölçeğinin tek boyutlu yapıda incelenebileceği tespit edilmiştir. Ölçeğe ait bu tek boyut, toplam varyansın \%71,43'ünü açıklamaktadır.

Ayrıca ölçeklerin güvenilirlik testleri için Cronbach Alpha katsayıları hesaplanmış ve Tablo 3 'te boyutların karşılarında gösterilmiştir. Buna göre 4 ifadeden oluşan duyuşsal boyut $0,918,5$ ifadeden oluşan bilişsel boyut 0,863 ve 4 ifadeden oluşan davranışsal boyut 0,685 Cronbach Alpha değerine sahiptir. Sinizm ölçeği tümüyle güvenilirlik analizine tabi tutulduğunda, 13 soruluk ölçeğin Cronbach Alpha değeri 0,826 olarak bulunmuştur. Tek boyut ve 5 ifadeden oluşan sosyal izolasyon ölçeğine ait Cronbach Alpha değeri ise 0,894 olarak tespit edilmiştir. Bu oranlar, ölçeğin yeterli düzeyde güvenilir olduğunu göstermektedir.

\section{BULGULAR}

Araştırmada bağımlı ve bağımsız değişkenler arasındaki ilişkileri ortaya çıkarmak amacıyla, Pearson korelasyon analizi yapılmış ve korelasyon bulguları Tablo 4'te gösterilmiştir. Analiz sonuçlarına göre, sosyal izolasyon ve duyuşsal sinizm arasında $(\mathrm{r}=0,555 ; \mathrm{p}=0,000)$, sosyal izolasyon ve bilişsel sinizm arasında $(r=0,578 ; p=0,000)$ ve sosyal izolasyon ve davranışsal sinizm arasında $(r=0,545$; $\mathrm{p}=0,000)$ istatistiksel bakımdan anlamlı ve pozitif bir ilişki tespit edilmiştir. Değişkenlerin ortalama ve standart sapma değerleri incelendiğinde, sosyal izolasyon ortalamasının 2,6593, duyuşsal sinizm ortalamasının 1,9167, bilişsel sinizm ortalamasının 2,3951 ve davranışsal sinizm ortalamasının 2,9321 olduğu görülmektedir. 
Tablo 4. Değişkenlerin Ortalama, Standart Sapma ve Korelasyon Bulguları $(n=162)$

\begin{tabular}{lrrccc}
\hline \multicolumn{1}{c}{ ÖLÇEKLER } & Ortalama & Std. Sap. & $\mathbf{1}$ & $\mathbf{2}$ & \multicolumn{1}{c}{$\mathbf{3}$} \\
\hline Sosyal İzolasyon & 2,6593 &, 90900 &, $555^{*}$ &, $578^{*}$ &, $545^{*}$ \\
1- Duyuşsal Sinizm & 1,9167 &, 71692 & 1 &, $693^{*}$ &, $639^{*}$ \\
2- Bilişsel Sinizm & 2,3951 &, 73322 & & 1 &, $634^{*}$ \\
3- Davranışsal Sinizm & 2,9321 &, 74456 & & & 1 \\
\hline
\end{tabular}

*p<0,001

Araştırmada, sosyal izolasyonun genel olarak örgütsel sinizm üzerindeki etkisini inceleyebilmek amacıyla regresyon analizi yapılmıştır. Elde edilen bulgular, Tablo 5'te gösterilmiştir. Bu doğrultuda sosyal izolasyonun örgütsel sinizm üzerinde pozitif yönlü ve istatistiksel açıdan anlamlı etkisinin olduğu görülmüştür $(p<0,05)$. Elde edilen sonuçlara göre sosyal izolasyonun, örgütsel sinizme ait varyansı \%43,5 oranında açıkladığı, başka bir deyişle örgütsel sinizmin \% $\% 3,5$ oranında sosyal izolasyona bağlı olarak şekillendiği anlaşılmaktadır.

Tablo 5. Sosyal İzolasyon ve Örgütsel Sinizm Arasındaki Regresyon Analizi

\begin{tabular}{cccccccc}
\hline $\begin{array}{c}\text { Bă̆ımlı } \\
\text { Değişken }\end{array}$ & $\mathbf{R}^{2}$ & $\begin{array}{c}\text { Bağımsız } \\
\text { Değişken }\end{array}$ & B & SS. & $\mathbf{t}$ & $\mathbf{p}$ & $\mathbf{F}$ \\
\hline $\begin{array}{c}\text { Örgütsel } \\
\text { Sinizm }\end{array}$ & 0,435 & Sabit & 1,401 & 0,096 & 14,544 & 0,000 & \\
\hline $\mathrm{R}=0,659$ & $* \mathrm{p}<0,001$ & Sosyal İzolasyon & 0,381 & 0,034 & 11,095 & 0,000 & \\
\hline
\end{tabular}

Sosyal izolasyonun örgütsel sinizm üzerindeki etkisini incelerken, ayrıca örgütsel sinizm boyutları açısından bir değerlendirme yapmak hedeflenmiştir. Araştırmada, bağımsız değişkenin (Sosyal izolasyon), bağımlı değişkenler (Örgütsel sinizm boyutları) üzerindeki etkilerini incelemek amacıyla oluşturulan hipotezleri test edebilmek için tek yönlü manova testi yapılmıştır. Çünkü birden fazla bağımlı değişkene tek bir bağımsız değişkenin etki ettiği durumlarda tek yönlü manova analizi kullanılmaktadır (Kalaycı, 2010: 155). Manova testi, birden fazla bağımlı değişkenin bulunduğu çoklu regresyon analizlerinde kullanılan bir yöntemdir.

Tek yönlü manova testinin güvenilir sonuçlar verebilmesi için bazı koşulların sağlanmış olması gerekmektedir (Can, 2014: 192-193):

1. Veriler, tek değişkenli ve çok değişkenli normal dağılım sergilemelidir.

2. Bağımlı değişkenler arasında makul düzeyde doğrusal ilişki olmalıdır. olmamalıdir.

3. Bağımlı değişkenlere ait kovaryanslar arasında anlamlı fark

4. Bağımlı değişkenlere ait hata varyansları homojen olmalıdır.

5. Her bir veri diğerinden bağımsız olmalıdır. 
Tek yönlü manova testinin güvenilirliği için ilk önce tek değişkenli normallik kontrolü yapılmıştır. Bağımlı değişkenin, bağımsız değişkenin kategorilerindeki normallik testi sonucu, verilerin tek değişkenli normal dağılım sergilediğini göstermiştir. Ayrıca merkezi eğilim, ortanca ve tepe değerler incelendiğinde, bu değerlerin birbirine yakın olduğu, göze batan bir çarpıklığın ya da basıklığın bulunmadığı görülmüştür. Ayrıca kutu-çizgi grafiği incelenmiş ve verilerin tek değişkenli normallik açısından herhangi bir uç değer içermediği tespit edilmiştir. Çok değişkenli normallik (her bir değişkenin, diğer değişkenlerin kombinasyonlarında normal dağılım sergiliyor olması) testi ise Mahalanobis uzaklıkları aracılığıyla kontrol edilmiştir. Burada kritik değeri aşarak çok değişkenli normalliği bozan bir uç değere rastlanmamıştır. Dolayısıyla verilere ait tek değişkenli ve çok değişkenli normallik koşullarının sağlandığı, başka bir deyişle verilerin normal dağıldığg görülmüştür.

Testin güvenilirliği için normallik incelemesinden sonra, bağımlı değişkenler arasındaki ilişki kontrol edilmiştir. Tablo 4'teki verilere bakıldığında, bağımlı değişkenler arasında makul düzeyde ilişki olduğu ve herhangi bir çoklu bağlantılılık sorununun olmadığı tespit edilmiştir.

Bağımlı değişkenlere ait popülasyon kovaryanslarının eşitliği hipotezi Box $\mathrm{M}$ testi ile kontrol edilmiştir. Bu aşamada kurgulanan hipotezler şöyledir:

$\mathrm{H}_{0}$ : Varyans-kovaryans matrisleri eşittir.

$\mathrm{H}_{1}$ : Varyans-kovaryans matrisleri eşit değildir.

Sonuçlara göre gruplar üzerinden gözlenen varyans kovaryans matrislerinin eşitliği hipotezi (H0) istenildiği üzere kabul edilmiştir (Box M test= $61,951 ; p=0,268 ; p>, 05)$. Bu sonuç varyans-kovaryans matrislerinin birbirine eşit olduğu anlamına gelmektedir. Her bir bağımlı değişkenin varyanslarını inceleyebilmek için Levene testi uygulanmıştır. Levene testi sonuçlarına göre, üç bağımlı değişkene ait anlamlılık düzeyleri ,05'ten büyük olduğu için tüm bağımlı değişkenlere ait varyansların homojenliği ayrı ayrı desteklenmiş, bağımlı değişkenlere ait hata varyanslarının homojen olduğu görülmüsstür.

Tüm bu değerlendirmeler 1şığında tek yönlü manova testinin güvenilirliği için gerekli olan tüm koşulların sağlandığ görülmüş ve test sonuçları değerlendirmeye alınmıştır. Manova analizi sonuçlarında Wilks' Lambda değerleri dikkate alınmıştır. Buna göre, sosyal izolasyon düzeyinin üç örgütsel sinizm boyutu üzerinde istatistiksel olarak anlamlı şekilde etkisi olduğu görülmektedir $(F(51-424)=5,447 ; p=0,000$; Wilks' Lambda=0,223).

Tablo 6'da gösterilen ve her bir faktör için gerçekleştirilen tek yönlü manova analizi sonuçlarına göre ise, sosyal izolasyonun duyuşsal sinizm $(\mathrm{F}=$ $12,259, \mathrm{p}<0,05)$, bilişsel sinizm $(\mathrm{F}=11,836, \mathrm{p}<0,05)$ ve davranışsal sinizm $(\mathrm{F}=$ $1,798, \mathrm{p}<0,05)$ üzerindeki etkisi istatistiksel açıdan anlamlı olarak tespit edilmiştir. Tablodaki etki değerleri incelendiğinde, çalışanların sosyal izolasyon düzeylerinin en çok duyuşsal sinizmi etkilediği görülmektedir $(\mathrm{R}=0,591)$. Ayrıca sosyal izolasyon düzeyinin bilişsel sinizmi yüksek düzeyde $(\mathrm{R}=0,583)$, davranışsal sinizmi ise düşük düzeyde $(\mathrm{R}=0,175)$ etkilediği sonucuna ulaşılmıştır. 
Tablo 6. Sosyal İzolasyonun Örgütsel Sinizm Boyutları Üzerindeki Etkisine İlişkin

\begin{tabular}{|c|c|c|c|c|r|r|r|}
\hline $\begin{array}{c}\text { Bağımsız } \\
\text { Değişken }\end{array}$ & Bağımlı Değişkenler & $\begin{array}{c}\text { Sum of } \\
\text { Squares }\end{array}$ & df & $\begin{array}{c}\text { Mean } \\
\text { Square }\end{array}$ & F & $\begin{array}{c}\text { Sig. } \\
\text { (p) }\end{array}$ & R Sq.* \\
\hline \multirow{2}{*}{$\begin{array}{c}\text { Sosyal } \\
\text { İzolasyon }\end{array}$} & Duyuşsal Sinizm & 48,937 & 17 & 2,879 & 12,259 &, 000 &, 591 \\
\cline { 2 - 8 } & Bilişsel Sinizm & 50,451 & 17 & 2,968 & 11,836 &, 000 &, 583 \\
\cline { 2 - 8 } & Davranışsal Sinizm & 15,626 & 17 & 0,919 & 1,798 &, 033 &, 175 \\
\hline
\end{tabular}

\section{Manova Testi Bulguları}

* Doğrudan etki incelemesi yapıldığı için R Squared değerleri dikkate alınmıştır.

\section{SONUC}

$\mathrm{Bu}$ araştırma, sosyal açıdan izole olmuş bir bireyin, çalıştığ örgüte karşı olumsuz duygular ve davranışlar içerisine girebileceği varsayımıyla kurgulanmıştır. $\mathrm{Bu}$ varsayımdan hareketle çalışmanın amacı, sosyal izolasyonun örgütsel sinizm üzerindeki etkisini incelemektir. Bu amaçla örgütsel sinizm ve sosyal izolasyon kavramları hakkında çalışmanın teorik çerçevesi oluşturulmuş ve örneklem üzerindeki durumu analiz edilmiştir.

Araştırmada kullanılan ölçeklerin geçerlilik ve güvenirlik testleri yapıldıktan sonra, sosyal izolasyon ile örgütsel sinizm boyutları arasında istatistiksel bakımdan anlamlı bir ilişki olup olmadığını incelemek için Pearson İlişki Analizi yapılmıştır. Elde edilen bulgulara göre, sosyal izolasyon ile duyuşsal sinizm, bilişsel sinizm ve davranışsal sinizm arasında istatistiksel bakımdan anlamlı ve pozitif ilişki tespit edilmiştir.

Araştırmada elde edilen ortalama değerler incelendiğinde, en yüksek ortalamaya sahip örgütsel sinizm boyutunun davranışsal sinizm $(x=2,9321)$ olduğu görülmüştür. Bu boyutu sırasıyla bilişsel sinizm $(\mathrm{x}=2,3951)$ ve duyuşsal sinizm $(x=1,9167)$ izlemektedir. Sosyal izolasyona ilişkin ortalama değer ise 2,6593 olarak tespit edilmiştir. Bu değerler, örnekleme dahil edilen çalışanların sosyal izolasyon ve örgütsel sinizm düzeylerinin genel olarak orta düzeyde olduğunu göstermektedir.

Araştırmada, sosyal izolasyonun genel olarak örgütsel sinizm üzerindeki etkisini inceleyebilmek amacıyla regresyon analizi yapılmıştır. Elde edilen bulgulara göre, sosyal izolasyonun örgütsel sinizm üzerinde pozitif yönlü ve istatistiksel açıdan anlamlı etkisinin olduğu görülmüştür $(\mathrm{p}<0,05)$. Bu sonuçlara göre sosyal izolasyonun, örgütsel sinizme ait varyans $1 \% 43,5$ oranında açıkladığ 1 , başka bir deyişle örgütsel sinizmin \% 43,5 oranında sosyal izolasyona bağlı olarak şekillendiği anlaşılmaktadır. Sosyal izolasyonun örgütsel sinizm üzerindeki etkisini incelerken, ayrıca örgütsel sinizm boyutları açısından bir değerlendirme yapmak hedeflenmiştir. Araştırmada, bağımsız değişkenin (Sosyal izolasyon), bağımlı değişkenler (Örgütsel sinizm boyutları) üzerindeki etkilerini incelemek amaciyla oluşturulan hipotezleri test edebilmek için tek yönlü manova testi yapılmıştır. Bu doğrultuda, çalışanların sosyal izolasyon düzeylerinin örgütsel sinizm boyutlarının üçünü de istatistiksel açıdan anlamlı şekilde etkilediği bulgulanmıştır. Veriler daha detaylı incelendiğinde sosyal izolasyonun en çok duyuşsal sinizmi etkilediği bulgulanmıştır. Ayrıca sosyal izolasyon düzeyinin bilişsel sinizmi yüksek düzeyde, davranışsal sinizmi ise düşük düzeyde etkilediği 
sonucuna ulaşılmıştır. Bu kapsamda oluşturulan " $\mathrm{H}_{1}$ : Sosyal izolasyon, duyuşsal sinizmi etkiler.", " $\mathrm{H}_{2}$ : Sosyal izolasyon, bilişsel sinizmi etkiler." ve " $\mathrm{H}_{3}$ : Sosyal izolasyon, davranışsal sinizmi etkiler." hipotezlerinin üçü de kabul edilmiştir. Araştırmadan elde edilen bu bulgular, alanyazında benzer bir araştırmaya rastlanmadığından dolayı karşılaştırmaya tabi tutulamamıştır.

Araştırmada, katılımcıların yanıtladıkları cevapların var olan durumu yansıttığı ve samimi bir şekilde cevap verdikleri varsayılmaktadır. Bu varsayımla birlikte araştırmanın iki önemli sınırlılığı bulunmaktadır. Bunlardan ilki, araştırma evreninin Konya'da hizmet vermekte olan tarım makineleri imalatçısı 5 işletme çalışanlarıyla sınırlı olmasıdır. İkinci sınırlılık ise, sadece anketi doldurmayı kabul eden ve anketin yapıldığ gün ve saatlerde ilgili işletmelerde olan çalışanlara anketlerin uygulanmış olmasıdır. Araştırmanın daha geniş ve/veya farklı evren ve örneklemlerde uygulanarak sonuçların karşılaştırılması mümkün olabilir.

\section{KAYNAKÇA}

Acar, Aslı B., Dündar, G. (2008). İşyerinde psikolojik yıldırmaya (mobbing) maruz kalma sıklığı ile demografik özellikler arasındaki ilişkinin incelenmesi. İstanbul Üniversitesi İşletme Fakültesi Dergisi, 37 (2), 111-120.

Akman, G. (2013). Sağlık Çalışanlarının Örgütsel ve Genel Sinizm Düzeylerinin Karşılaştırılması. İstanbul Üniversitesi Sosyal Bilimler Enstitüsü, Yüksek Lisans Tezi, İstanbul.

Bachrach, C. (1980). Childlessness and Social Isolation, National Council on Family Relations. Journal of Marriage and Family, 42 (3), 627-637.

Bartlett, Maurice S. (1950). Tests of Significance in Factor Analysis. British Journal of Mathematical and Statistical Psychology, 3 (2), 77-85.

Bibb, S., Kourdi, J. (2004). Trust Matters: For Organizational and Personal Success. New YorkUSA: Palgrave Macmillan.

Brandes, P., Dharwadkar, R. \& Dean, J.W. (1999). Does Organizational Cynicism Matter? Employee and Supervisor Perspectives on Work Outcomes. Eastern Academy of Management Proceedings, 150-153.

Brown, S.J., Learmonth, M.A. \& Mackereth, J.C. (2015). Promoting Public Mental Health and Well-Being; Principles into Practice. London: Jessica Kingsley.

Cacioppo, J., Hawkley, L. \& Thisted, R. (2010). Perceived Social Isolation Makes Me Sad: 5-Year Cross-Lagged Analyses of Loneliness and Depressive Symptomatology in the Chicago Health, Aging, and Social Relations Study. Psychology and Aging, 25 (2), 453-463.

Can, A. (2014). SPSS İle Bilimsel Araştırma Sürecinde Nicel Veri Analizi (3. Bask1), Ankara: Pegem.

Cappella, N.J., Jamieson, H.K. (1997). Spiral of Cynicism: The Press and the Public Good. UK: Oxford University.

Clegg, S., Bailey, R.J. (2007). International Encyclopedia of Organization Studies. USA: SAGE.

Cornwell, E., Waite, L. (2009). Social Disconnectedness, Percived Isolation, and Health among Older Adults. Journal of Health and Social Behavior, 50 (1), 31-48.

Dean, J., Brandes, P. \& Dharwadkar, R. (1998). Organizational Cynicism. USA: Academy of Management.

De Jong Gierveld, J., van Tilburg, T.G. \& Dykstra, P.A. (2006). Loneliness and Social Isolation. D. Perlman and A. Vangelisti (Ed.), The Cambridge Handbok of Personal Relationships, Cambridge-UK: Cambridge University.

Elliott, J. (1999). Social Isolation and Labor Market Insulation: Network and Neighborhood Effects on Less-Educated Urban Workers. The Sociological Quarterly, 40 (2), 199-216.

Geschwender, J. (1968). Status Inconsistency, Social Isolation, and Individual Unrest. Social Forces, 46 (4), 477-483. 
Graen, B.G., Graen, A.J. (2006). Sharing Network Leadership, A Volume In LMX Leadership: The Series. USA: Information Age.

Gün, Gül (2016). Otel İşletmelerinde Mobbing ve Örgütsel Sinizm İlişkisi: Bitlis İlinde Bir Çalışma. International Journal of Social Science, 52, 201-219.

Hawton, A., Green, C., Dickens, A., Richards, S., Taylor, R., Edwards, R., Greaves, C. \& Campbell, J. (2011). The Impact of Social Isolation on the Health Status and Health-Related Quality of Life of Older People. Quality of Life Research, 20 (1), 57-67.

Hortulanus, R., Machielse, A. \& Meeuwesen, L. (2006). Social Isolation in Modern Society. OxonUK: Routledge.

Kalayc1, Ş. (2010). SPSS Uygulamalı Çok Değişkenli İstatistik Teknikleri (5. Baskı). Ankara: Asil.

Karacaoğlu, K., İnce, F. (2012). Brandes, Dharwadkar ve Dean'in (1999) Örgütsel Sinizm Ölçeği Türkçe Formunun Geçerlilik ve Güvenilirlik Çalışması: Kayseri Organize Sanayi Bölgesi Örneği. Business and Economics Research Journal, 3 (3), 77-92.

Karelina, K., Norman, G., Zhang, N., Morris, J., Peng, H., DeVries, C. \& Greenough, W. (2009). Social Isolation Alters Neuroinflammatory Response to Stroke. Proceedings of the National Academy of Sciences of the United States of America, 106 (14), 5895-5900.

Keyes, D. (2006). Seeing Through Cynicism: A Reconsideration of the Power of Suspicion. USA: InterVarsity.

Kılıç, Z. (2009). İnmeli Hastalarda Santral Ă̆rı Değerlendirmesi. İstanbul Fizik Tedavi ve Rehabilitasyon Eğitim ve Araştırma Hastanesi 1. Klinik, Uzmanlık Tezi, İstanbul.

Krings-Ernst, D. (2011). Organizational Structure and the Disciples of the Dog. Organizational Cynicism. Norderstedt-Germany: GRIN Verlag.

Kökalan, Ö., Anaş, K. (2016). Çalışanların Örgütsel Sinizm Tutumlarının İşe Yabancılaşmaları Üzerine Etkisi: Vakıf Üniversiteleri Üzerine Bir Çalışma. Bilgi Ekonomisi ve Yönetimi Dergisi, XI (II), 97-109.

Küçükdeveci, A.A., McKenna S.P., Kutlay, Ş., Gürsel, Y., Whalley D. \& Arasil, T. (2000). The development and psychometric assessment of the Turkish version of the Nottingham Health Profile. International Journal of Rehabilitation Research, 23 (1), 31-38.

Laursen, B., Bukowski, M.W., Aunola, K. \& Nurmi, J. (2007). Friendship Moderates Prospective Associations bbetween Social Isolation and Adjustment Problems in Young Children. Society for Research in Child Development, Wiley, 1395-1404.

Leymann H. (1990). Mobbing and psychological terror at workplace. Violence Vict, 5 (2), 119-126.

Mazella, D. (2007). The Making of Modern Cynicism. USA: University of Virginia.

Oxford Dictionary of English (2010). A. Stevenson (Ed.), UK: Oxford University.

Reeder, L., Reeder, S. (1969). Social Isolation and Illegitimacy, National Council on Family Relations. Journal of Marriage and Family, 31 (3), 451-461.

Rokach, A. and Wright, S. (2013). Loneliness Updated: Recent Research on Loneliness and How it Affects our Lives, Is it Lonely at the Top? An Empirical Study of Managers' and Nonmanagers' Loneliness in Organizations, Oxon-UK: Routledge.

Rovai, P.A., Baker, D.J. \& Ponton, K.M. (2014). Social Science Research Design and Statistics: A Practitioner's Guide to Research Methods and IBM SPSS. USA: Watertree.

Tavşancıl, E. (2010). Tutumların Ölçülmesi ve Spss ile Veri Analizi. Ankara: Nobel.

Tigges, L., Browne, I. \& Green, G. (1998). Social Isolation of the Urban Poor: Race, Class, and Neighborhood Effects on Social Resources. The Sociological Quarterly, 39 (1), 53-77.

Samuel, K., Alkire, S., Hammock, J., Mills, C. \& Zavaleta D. (2014). Social Isolation and its Relationship to Multidimensional Poverty. OPHI Working Paper No. 80, UK: University of Oxford.

Samuel, K. (2015). Age Acceptance: Implications and Opportunities for Emerging Markets. Emerging Markets Symposium, Green Templeton College, UK: University of Oxford.

Schreier, B. (2009). The Power of Negative Thinking: Cynicism and the History of Modern American Literature. USA: University of Virginia.

Siegel, B. (1998). The World of the Autistic Child: Understanding and Treating Autistic Spectrum Disorder. UK: Oxford University. 
Uribe, L. (2007). Social Isolation and Sexual Risk Behavior Among Recently Arrived Male Hispanic Migrants in Durham, North Carolina. North Carolina-USA: The University of North Carolina at Chapel Hill.

Van Erp, S., Verstricht, L. (2008). Longing in a Culture of Cynicism. Austria: LIT Verlag Munster. Vice, S. (2011). Cynicism and Morality. Ethical Theory and Moral Practice, 14 (2), 169-184.

Victor, C, Scambler, S. \& Bond, J. (2008). The Social World of Older People: Understanding Loneliness and Social Isolation in Later Life: Growing Older. A. Walker (Ed.), BerkshireUK: McGraw-Hill.

Yıldız, K., Akgün, N., Yıldız, S. (2013). İşe Yabancılaşma ile Örgütsel Sinizm Arasındaki İlişki. The Journal of Academic Social Science Studies, 6 (6), 1253-1284.

\section{SUMMARY}

The model of the present research is based on the hypothesis that socially isolated employees have a negative attitude towards their organization due their negative perspectives of life. Within the scope of this model, the purpose of the present research is investigating the effect of social isolation on organizational cynicism. The research is designed in accordance with quantitative research approach, and adopted non-experimental relational research method. For this purpose, data collected via questionnaires from 162 employees of 5 agricultural machinery-manufacture businesses in the province of Konya were analysed. Measures of central tendency and descriptive statistics were used for analyses, and correlation and regression analyses and MANOVA test were utilized. KMO and Bartlett test results for the scales are within the required range. According to factor analysis results, organizational cynicism scale didn't present difference from the original scale, and was analysed in three dimensions. Additionally, social isolation scale was analysed in single dimension as the original scale.

According to the findings, there are statistically significant positive correlations between social isolation and affective cynicism; and between cognitive cynicism and behavioural cynicism. Another finding of the present research is that, social isolation and organizational cynicism levels of employees in the sample are generally within medium level range.

The present research found that social isolation had a statistically significant effect on organizational cynicism. Additionally, the effect of social isolation of organizational cynicism dimensions was also analysed. According to the obtained findings, social isolation has statistically significant effects on all three dimensions (affective, cognitive, and behavioural) of organizational cynicism. Accordingly, all three hypotheses of the present research " $\mathrm{H}_{1}$ : Social isolation effects affective cynicism.", " $\mathrm{H}_{2}$ : Social isolation effects cognitive cynicism.", and " $\mathrm{H}_{3}$ : Social isolation effects behavioural cynicism." are accepted. It was also found that social isolation levels of employees effected affective cynicism most. Finally, it was found that social isolation levels effected cognitive cynicism at high level, and behavioural cynicism at low level. 